\title{
УДК:633.15:57.086.83 \\ https://doi.org/10.53040/gppb7.2021.53 \\ ИЗУЧЕНИЕ ПОТЕНЦИАЛА ХРАНЕНИЯ КОЛЛЕКЦИОННЫХ ОБРАЗЦОВ КУКУРУЗЫ (Zea mays L.) В УСЛОВИЯХ КОНСЕРВАЦИИ ЕX SITU
}

\author{
Корлэтяну Л. ${ }^{1}$, Мелиян Л. ${ }^{1}$, Ганя $A^{1}$, Михаилэ В. ${ }^{1}$, Ванькович ${ }^{2}{ }^{2}$ \\ Институт генетики, физиологии и защиты растений, Кишинэу, Республика Молдова \\ ${ }^{2}$ Институт растениеводства "Порумбень", Пашкань, Республика Молдова \\ e-mail: liudmila.corlateanu@igfpp.md
}

\begin{abstract}
Seed storage potential (SP) is an important complex indicator characterizing the ability of collection samples to be conserved ex situ in a genetic bank. The accelerated aging test (AA test) was used to determine the storage potential of maize samples. The AA test for maize seeds was carried out at $43-44^{\circ} \mathrm{C}, 90-100 \%$ relative humidity, with an aging time of 96 hours. After the test, various morphophysiological parameters were determined on 8 collection maize samples: germination energy and seed germination, root length and quantity, wet and dry root biomass. The maize genotypes were divided into 3 groups according to various post-test indicators: group 1 (high SP) - genotypes P235; P 310; P243; group 2 (medium SP) - genotypes P 402, Р 383, Р 465; group 3 (low SP) - genotypes P 461 и Р 427. Thus, the use of AA test on maize collection samples based on morphophysiological characteristics allows gradation of genotypes by seed SP.
\end{abstract}

Key words: storage potential, genetic bank, maize, seed germination, root length.

\section{Введение}

При длительной консервации ex situ зародышевой плазмы растений в генетических банках основной задачей является сохранение жизнеспособности семян, т.к. в них происходят процессы старения и семенной материал постепенно теряет всхожесть и генетическую однородность $[9,11]$. Поэтому изучение потенциала хранения (ПХ) семян является очень важным этапом для консервации ex situ генетических ресурсов растений, особенно при длительном хранении коллекционных образцов в генетическом банке растений. Определение данного потенциала в последние годы стали проводить во многих генетических банках растений разных стран [1;2;4;6]. Известно, что долговечность семян зависит не только от их условий хранения, но и от их исходной всхожести, размера, спелости, условий выращивания, наличия или отсутствия патогенов, видовых особенностей и многих других факторов. Иногда все эти факторы трудно учесть при закладке на хранение ex situ зародышевой плазмы [7; 8; 9]. Для изучения данных вопросов большой интерес представляет метод ускоренного старения семян, суть которого заключается в искусственном ускорении процесса старения путем экспозиции семян в течение непродолжительного времени при повышенной температуре и высокой относительной влажности воздуха [5]. Ускоренное старение семян в большой степени используется для определения силы роста семян [10]. Существуют ряд работ, в которых сопоставлялись физиолого-биохимические изменения в семенах при ускоренном старении и длительном хранении. Ускоренное старение семян позволяет оценивать различия между сортами различных видов сельскохозяйственных культур. С помощью теста можно осуществлять мониторинг образцов генофонда, т.е. проводить постоянный учет жизнеспособности семян и классифицировать генотипы из рабочих и активных коллекций по параметрам старения семян. Тест позволяет: 1. Выявлять образцы, не пригодные к длительному хранению. 2. Давать рекомендации по срокам воспроизводства семян. 3. Указывать на необходимость восстановления ЖБ особенно ценных коллекционных образцов.

Целью данных исследований было изучить различные морфофизиологические параметры семян и проростков кукурузы после применения теста на ускоренное старение семян, определить их потенциал хранения и провести градацию генотипов по данному признаку.

\section{Материалы и методы}

Потенциал хранения коллекционных образцов кукурузы определяли с использованием теста на УСТ семян. Для проведения данного теста применяли общепринятые в международной практике методики, описанные в Handbook of vigour test methods [3]. Для семян кукурузы рекомендуется проводить тест при температуре $41^{\circ} \mathrm{C}$, относительной влажности воздуха 90 - 100\%, срок старения - 72 часа. Иногда требуется корректировка этих условий при старении семян конкретного генотипа. Для неко- 
торых образцов кукурузы была подобрана другая температура старения $-43-44{ }^{\circ} \mathrm{C}$ и другой срок старения - 96 часов. Тестировались следующие коллекционные образцы кукурузы: генотипы местной селекции, созданные в Институте растениеводства "Порумбень": Р 235; Р 310; Р 243; Р 402; Р 383; Р 465; Р 461, Р 427 из активной коллекции генетического банка растений Молдовы. После проведения теста на ускоренное старение семена проращивали в термостате при температуре $25^{\circ} \mathrm{C}$. В каждом варианте было по 300 семян, эксперименты проводились в 3-х кратной повторности. Контролем являлись нормальные семена кукурузы последней репродукции. Экспериментальные данные были обработаны с использованием пакета программ Statistica. После проведения ускоренного старения семян определяли различные морфофизиологические параметры семян и проростков кукурузы: энергию прорастания и всхожесть семян, длину и число корешков, сырую и сухую биомассу корешков согласно Международным правилам тестирования семян ISTA (5).

\section{Результаты и обсуждение}

Снижение энергии прорастания и всхожести семян кукурузы после проведения теста на УСТ по сравнению с контролем составило для разных генотипов кукурузы соответственно 7,5 - 48,1\% и 13,2 - 74,0\%, что может свидетельствовать о генотипической специфичности тестируемых образцов. Генотипы кукурузы по таким важным показателям как энергия прорастания и всхожесть семян были подразделены на 3 группы с учетом изменения этих параметров после проведения теста. В 1-ю группу (высокий ПХ) вошли генотипы Р 235, Р 310 и Р 243; во 2-ю группу (средний ПХ) - генотипы Р 402, Р 383 и Р 465; в 3-ю группу (низкий ПХ) - генотипы Р 461 и Р 427 (рис. 1).

В первой группе генотипов кукурузы (высокий ПХ) после УСТ всхожесть семян составила 70,0 - 86,8\%. Падение всхожести семян по сравнению с контролем было на уровне $13,2-28,0 \%$. Во второй группе генотипов (средний ПХ) после УСТ всхожесть семян составила 49,7 - 60,6\%; уменьшение данного параметра по сравнению с контролем $38,1-47,0 \%$.

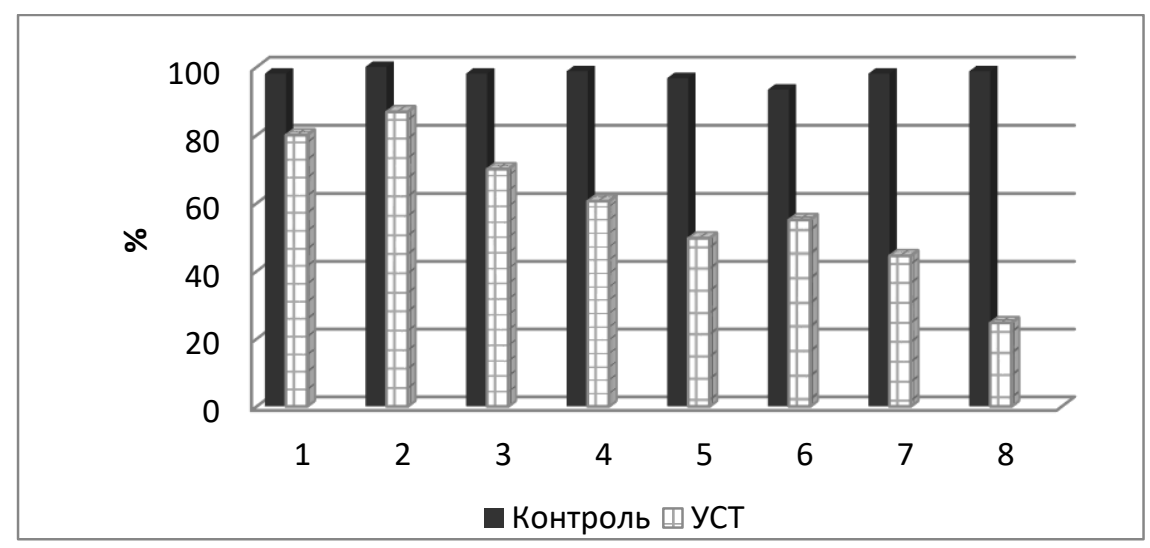

Рис. Изменение всхожести семян кукурузы после теста на УСТ, \%. Примечание: к - контроль, УСТ - ускоренное старение. Генотипы: 1 - Р 235, 2 - Р 310, 3 - Р 243, 4 - Р 383, 5 - P 465, 6 - Р 402, 7 - P 461, 8 - P 427

Всхожесть семян в 3-й группе (низкий ПХ) после проведения теста была соответственно 44,5\% (Р 461) и 24,7\% (Р 427). В данном случае падение всхожести было максимальным: 53,5 и 74,0\% (в контроле всхожесть семян была соответственно 98,0 и 98,7\%).

После УСТ семян различных генотипов кукурузы наблюдалось изменение и других морфофизиологических параметров (длины и количества корешков, сырой и сухой биомассы корешков). Длина корешков семян после ускоренного старения варьировала от 9,0 до 14,9 мм в зависимости от генотипа.

Максимальным угнетением развития корневой системы после действия высокой температуры и влажности воздуха отличались семена образцов Р 383 и Р 465 (средний ПХ), уменьшение длины корешков после проведения теста в данных вариантах по сравнению с контролем составило 11,8 и 12,1 мм (табл.). В среднем у разных генотипов кукурузы сырая биомасса корешков в контроле колебалась от 0,44 до 0,74 мг, а после тестирования падение сырой биомассы составило 0,07 - 0,36 мг по сравнению с контролем. Биомасса корешков максимально уменьшилась у генотипов Р 383 и $\mathrm{P}$ 465 (средний ПХ) - на 0,27 и 0,31 мг, что совпало с длиной корешков. Меньше пострадала корневая система у образцов Р 235 (высокий ПХ) и Р 402 (средний ПХ), снижение сырой биомассы у них было незначительным. 
Таблица.Морфофизиологические параметры семян различных генотипов кукурузы после ускоренного старения

\begin{tabular}{|c|c|c|c|c|c|c|}
\hline \multirow{2}{*}{$\begin{array}{c}\text { Генотипы } \\
\text { кукурузы }\end{array}$} & \multicolumn{2}{|c|}{ Всхожесть семян, \% } & \multicolumn{2}{c|}{ Длина корешков, мм } & \multicolumn{2}{c|}{ Сырая биомасса 30-ти корешков, мг } \\
\cline { 2 - 7 } & Контроль & УСТ & Контроль & УСТ & Контроль & УСТ \\
\hline Р 461 & $98,0 \pm 1,7$ & $44,5 \pm 4,1^{*}$ & $14,0 \pm 2,1$ & $9,0 \pm 1,9^{*}$ & 0,44 & 0,15 \\
\hline P 427 & $98,7 \pm 1,7$ & $24,7 \pm 2,1^{*}$ & $12,5 \pm 1,6$ & $9,4 \pm 1,5^{*}$ & 0,62 & 0,36 \\
\hline P 383 & $98,7 \pm 1,6$ & $60,6 \pm 4,7^{*}$ & $24,0 \pm 2,0$ & $12,2 \pm 1,7^{*}$ & 0,73 & 0,46 \\
\hline P 465 & $96,7 \pm 5,3$ & $49,7 \pm 3,3^{*}$ & $18,6 \pm 0,9$ & $10,7 \pm 1,3^{*}$ & 0,65 & 0,34 \\
\hline P 402 & $93,3 \pm 5,3$ & $55,1 \pm 2,6^{*}$ & $13,0 \pm 1,4$ & $12,3 \pm 1,2$ & 0,45 & 0,38 \\
\hline P 235 & $98,0 \pm 2,0$ & $80,0 \pm 4,9^{*}$ & $15,8 \pm 2,1$ & $14,9 \pm 1,7$ & 0,47 & 0,41 \\
\hline P 310 & $100,0 \pm 0$ & $86,2 \pm 6,6^{*}$ & $17,5 \pm 1,5$ & $11,4 \pm 1,2^{*}$ & 0,61 & 0,34 \\
\hline P 243 & $98,0 \pm 2,0$ & $70,0 \pm 6,3^{*}$ & $21,8 \pm 1,9$ & $12,2 \pm 1,1^{*}$ & 0,74 & 0,38 \\
\hline
\end{tabular}

- - различия достоверны при $\mathrm{p}<0,05$

\section{Выводы}

1. Были предложены и апробированы новые условия старения семян кукурузы для местных гибридов: температура воздуха $-43-44{ }^{\circ} \mathrm{C}$, срок старения - 96 часов.

2. Тест на ускоренное старение семян позволяет определить потенциал их хранения, что дает возможность охарактеризовать способность коллекционных образцов кукурузы к долговременному хранению в генетическом банке растений.

3. По оценке коллекционных образцов кукурузы была проведена предварительная градация генотипов по потенциалу хранения семян. Генотипы были поделены на 3 группы: 1-ая группа (высокий ПХ) - Р 235, Р 310 и Р 243; 2-ая группа (средний ПХ) - генотипы Р 402, Р 383 и Р 465; 3-я группа (низкий ПХ) - генотипы Р 461 и Р 427.

4. Определение ПХ семян в условиях консервации ex situ позволяет: выявлять образцы, не пригодные к длительному хранению, что экономит средства для консервации; давать рекомендации по срокам воспроизводства семенного материала; указать на необходимость восстановления жизнеспособности коллекционных образцов.

Исследования проведены в рамках проекта Государственной Программы 20.80009.5107.11 "Длительное сохранение генетических ресурсов растений в генном банке с использованием методов молекулярной биологии в тестировании состояния здоровья растительной зародышевой плазмы”, финансируемой Национальным Агентством по Исследованиям и Развитию.

\section{Литература}

1. AGHILIAN, S.; KHAJEH-HOSSEINI, M.; ANVARKHAH, S. Evaluation of seed storage potential in forty medicinal plant species. International Journal of Agriculture and Crop Sciences. 2014, 7, 749-759.

2. DEMIR, I.; MAVIL, K. Controlled deterioration and accelerated aging tests to estimate the relative storage potential of cucurbit seed lots. HortScience. 2008, 43, 1544-1548.

3. HAMPTON, J. G.; TEKRONY, D. M. Handbook of vigor test methods. International Seed Testing Assn, Zurich, Switzerland. 1995. $120 \mathrm{p}$.

4. HAVSTAD, T.; AAMLID, T.; LOMHOLT, A. Evaluation of vigor tests for determination of seed storage potential in red clover (Trifolium pratensis L.) and timothy (Phleum pretense L.). Seeds Science and Technology. 2011, 39(3), 637-648.

5. International rules for seed testing. М.: Колос, 1984.310 c.

6. MIELEZRSKI, F.; MARCOS-FILNO, H. Assessment of physiological potential of stored pea (Pissum sativum L.) seeds. Journal of Seed Science. 2013, 35(1), 42-50.

7. NAGEL, M.; BORNER, A. The longevity of crop seeds stored under ambient conditions. Seed Science Research. 2010, 20(1), 1-12.

8. REHMAN ARIF, M.A.; NAGEL, M.; NEUMANN, K. et. al. Genetic studies of seed longevity in hexaploid wheat using segregation and association mapping approaches. Euphytica. 2012, 186(1), 1-13.

9. WALTERS, C.; WHEELER, L.M.; GROTENHUIS, J.M. Longevity of seeds stored in a genebank: species characteristic. Seed Science Research. 2005, 15(1), 1-20.

10. АЛЕКСЕЙЧУК, Г. Сила роста семян зерновых культур и ее оценка методом ускоренного старения. Минск. 2009. 43 с.

11. КОРЛЭТЯНУ, Л. Жизнеспособность семян культурных растений в условиях консервации ex situ при действии миллиметрового излучения. Кишинев. 2012. 156 с. 